\title{
Bridging the gap between farmers and food service directors: The social challenges in farm to school purchasing
}

\author{
Brandi Janssen* \\ University of Iowa
}

Submitted August 19, 2014 / Revised October 15 and November 5, 2014 / Accepted November 10, 2014 /

Published online December 9, 2014

Citation: Janssen, B. (2014). Bridging the gap between farmers and food service directors: The social

challenges in farm to school purchasing. Journal of Agriculture, Food Systems, and Community Development,

5(1), 129-143. http://dx.doi.org/10.5304/jafscd.2014.051.012

Copyright (C) 2014 by New Leaf Associates, Inc.

\begin{abstract}
Farm to school programs in which primary and secondary schools purchase locally grown products for school lunches aim to increase children's consumption of fresh foods while creating new markets for local food producers. However, the institutional purchasing of local foods can be fraught with difficulties. Many scholars have
\end{abstract}

\footnotetext{
* Brandi Janssen, Ph.D., Clinical Assistant Professor, Department of Occupational and Environmental Health; 145 Riverside Drive; S329 CPHB; University of Iowa; Iowa City, Iowa 52242 USA; +1-319-335-4190; brandi-janssen@ uiowa.edu
}

\section{Note}

This research was funded by the Wenner-Gren Foundation and The University of Iowa Center for Global and Regional Environmental Research. Portions of this paper were presented at the American Anthropological Association Annual Meeting in San Francisco in 2012.

\section{Disclosure}

Since 2011, the author has worked with the school district described here to develop procurement strategies for local products. There has been no financial benefit to the author. explored the structural challenges of local purchasing associated with cost, supply, and distribution. Less well examined are the ways that the different viewpoints and knowledge of farm to school participants affect procurement. This reflective essay provides a case study of local food purchasing at one medium-sized Midwestern public school district. Ethnographic examination of this process shows that local food farmers and school food service buyers have vastly different approaches to food production and handling. Attending to the social barriers of farm to school purchasing may improve participation by both farmers and food service directors.

\section{Keywords}

farm to school, farm to institution, local food, ethnography, school lunch, school procurement

\section{Introduction}

In recent decades, scholars and activists have mounted numerous criticisms against the current model of large-scale, industrialized agriculture, which is the basis of the centralized American food 
system (e.g. Goldschmidt, 1978; Kloppenburg, 1991; Pollan, 2006). In conjunction with such critiques, a number of alternative production and distribution strategies have developed. These include fair trade arrangements, which aim to empower small producers around the globe (Murray \& Raynolds, 2000), as well as more sustainable systems of production, such as organic farming (Belasco, 2007). Most recently, "local food" has become the fastest growing segment of the natural food industry and an important part of the sustainable agriculture movement (Ikerd, 2011). The term "local food" refers to agricultural products that are minimally processed and grown near the final point of sale. The phrase also refers to the various marketing strategies used by farmers to eliminate distributors, or "middle men," and sell their agricultural products directly to consumers, often via farmers markets or community supported agriculture (CSA) models.

Nationally, both farmers market attendance and CSA memberships have been growing at a steady rate. The national CSA directory, http://www.LocalHarvest.org, currently includes nearly 6,000 CSA farms. In 1994, when the United States Department of Agriculture (USDA) first began tracking and publishing numbers of farmers markets, there were 1,755 farmers markets in the U.S.; by 2012, there were 7,864 (USDA, 2014). These direct-marketing strategies are responsible for the basic framework of the current local food movement, in which communities are socially and economically enhanced by the practice of an embedded, "civic" agriculture (Kloppenburg, Lezberg, De Master, Stevenson, \& Hendrickson, 2000; Lyson, 2004; Swenson, 2009; Winter, 2003).

Institutions such as schools, hospitals, and retirement communities are also increasingly purchasing locally grown products (Friedmann, 2007). Schools are particularly important, both because of their consistent demands for food and because they are a primary food service outlet for children, who may benefit significantly from more healthy food offerings (Vogt \& Kaiser, 2008). Farm to school (sometimes called F2S) programs have seen remarkable growth nationwide. Farm to school typically includes an array of programs at the primary and secondary school level, including pur- chasing local foods for use in school lunches and snacks, school gardening initiatives, farm tours and agricultural literacy education, and nutrition education. Farm to school programs have garnered support from both state and federal legislative efforts. Supporters note that the phenomenon has opened new markets for farmers and increased children's exposure to healthier foods (National Farm to School Network, n.d.).

Despite the growing interest in farm to school programming, numerous challenges arise when public schools attempt to purchase unprocessed foods from local farmers. Cost is often cited as the key barrier to local procurement (Cooper \& Holmes, 2006; Joshi, Misako-Azuma, \& Feenstra, 2008). In addition, supply, packaging, and delivery represent significant barriers (Roche \& Kolodinsky, 2011). In this reflective essay, I examine some of the challenges of local food procurement from the perspective of both food service buyers and several farmers in a midsized Midwestern public school district. The case explored here supports many of the key barriers examined by other scholars. In addition, it elucidates that food service personnel and farmers have vastly different knowledge and beliefs about food and food handling. Local food farmers have developed strategies based on farmers markets and CSA models. In these interactions, the variability in size and seasonal availability of produce is seen as an opportunity to educate the individual consumer, who appreciates the personal, hands-on approach of the producer. However, a school food service buyer values consistency in both size and availability and appreciates attention to procedural details and documentation that ensure food safety. These social differences should be considered when attempting to overcome barriers in farm to school purchasing.

\section{Methods}

The information I present here is part of a larger ethnographic research project among local food producers in the Midwest, conducted from 2008 through 2012. Ethnography provides a close look at real situations in everyday life, and often ones in which the researcher has himself or herself been an integral part. Ethnographic attention to farming systems in the U.S. has been fruitful. Some ethnog- 
raphers (e.g., Fink, 1998; Horwitz, 1998; Rich, 2006) have worked in industrial hog barns and meat-packing plants. These researchers have been able to place their interviews and document analyses in the context of their observations of working conditions. They also have provided information about the social strategies of workers in industrial settings. Others (e.g., DeLind, 1999; Janssen, 2010) have used their experiences doing farm work on small farms to better understand the social processes that support, or do not support, the development of alternatives to industrial agriculture. Ziegenhorn (2000) combined ethnographic training with his experience as a farmer and as the owner of a small seed company to expose the methods by which large seed corporations innovate and market new varieties and the extent to which knowledge of these processes is kept from farmers. Others, such as Grey (2000), Ziegenhorn (1996), and Stull (2000) assisted farmers' groups and municipalities in writing grants or policy responses to the encroachment of industrial agriculture. Likewise, during this study I have played the part of both researcher and engaged volunteer. The methods of this study include 25 in-depth, semistructured interviews with farmers, attendance at several agricultural conferences, and participant observation on multiple small farms. My connections with farmers led to my involvement in several emergent farm to school programs. Since 2011, I have helped develop procurement strategies for the midsized district written about here.

The study presented here provides a clearer understanding of the various challenges associated with scaling up local food systems in general. The interactions between farmers and food service directors reveal that the two groups approach food production and procurement from significantly different perspectives, particularly in their approach to food handling. As a result, purchasing local foods can be difficult at nearly every stage of the process. First, there are significant time, equipment, and labor constraints in an institutional kitchen. Second, farmers and food service buyers may not use the same terminology to calculate product amounts. Third, the production and postharvest handling practices of farmers may not be acceptable to food service buyers, whose standards are based on different concerns. Finally, when purchasing local foods the food service buyer has no barrier to institutional liability between him- or herself and the food production site. In more conventional purchasing arrangements, a large corporate distributor protects the buyer from liability. In the case study that follows, we see that local food is acceptable to the school food buyer only after some of the elements of these more familiar transactions can be recreated.

\section{Farm to School Overview}

The National Farm to School Program traces its beginnings back to a few small pilot initiatives in Berkeley, California, and North Florida during the mid-1990s. By 2000, the USDA's Initiative for Future Agricultural and Food Systems (IFAFS) funded the National Farm to School Program to enable program and policy development and research. Members of the new National Farm to School Program attempted to gain more legislative support for farm to school by including a geographic preference clause in the 2002 farm bill. This clause allowed school food service directors to include a geographic preference for local foods in their bid specifications. In 2004, a federal farm to school grant program was established as part of the 2004 Child Nutrition Reauthorization Act, which amends the original Richard B. Russell National School Lunch Act every five years. However, funds were not appropriated for the program that year. Later, the 2010 Child Nutrition Reauthorization passed as the Healthy, HungerFree Kids Act and included funding for farm to school programs. Beginning in October 2012 US $\$ 5$ million per year was allocated to support farm to school programs at the local level. These funds have been disbursed nationwide as start-up grants for new farm to school chapters and project expansion grants for established programs.

The legislative mandates enacted in 2004 and 2010 related to farm to school "have dovetailed with the sustainable agriculture movement's ongoing interest in developing institutional markets and with national-level farm to school advocacy work by the National Farm to School Network, the Community Food Security Coalition and other groups" (Bagdonis, Hinrichs, \& Schafft, 2009, p. 
108). The goals of farm to school programs may contribute to more extensive fresh fruit and vegetable offerings in schools as well as broader education about food production (Story, Nanney, \& Schwartz, 2009). Public health professionals also promote farm to school programs as an early intervention for obesity prevention (Hamm, 2008).

\section{Farm to School Challenges}

In their overview of the literature on farm to school programs, Joshi, Misako-Azuma and Feenstra (2008) cite cost as the primary reason more school officials do not embrace local purchasing. The cost of ingredients is only partially responsible; the authors point out that costs are higher for the additional kitchen labor that is required, along with additional training for new production, delivery, and invoicing procedures (2008, p. 243). However, Izumi, Alaimo, and Hamm (2010) interviewed participating school food service professionals and found that local prices were often competitive with their typical distributors. In particular, they indicate the benefits of shortening the supply chain to eliminate transportation and handling costs of long distribution chains (Izumi, Alaimo, \& Hamm, 2010, p. 87). Limiting packaging may also reduce costs, as largescale distributors may line cardboard boxes with inserts or foam liners to protect the product. Local products, which are transported and handled less, may be packed loosely in food-grade boxes, further reducing costs. Flexible packaging options can, however, become problematic. A food service director from a small district reported to me in an interview that a producer once delivered green beans in a laundry basket, necessitating an explanation of the importance of food-grade packaging.

While the cost of local food may be either a barrier or a benefit, depending on the specific local situation, there are other features of institutional cooking that more clearly impede the ability of schools to use local products. Food safety concerns, in particular, may inhibit food service buyers from purchasing local food. Children younger than nine are considered a high-risk population for food-borne illness. All schools that participate in the National School Lunch Program are required to use food safety procedures based on the Hazard
Analysis and Critical Control Point (HACCP) system. A significant portion of HACCP procedures involve careful monitoring and recording of food, oven, and walk-in cooler temperatures. In particular, foods should be kept out of the "danger zone," which falls between 41 and 135 degrees Fahrenheit. Cold foods should remain below 41 degrees; hot foods should always be above 135 degrees.

Fears of food-borne illness, E. coli in particular, affect both meat and produce purchasing decisions and have, to some extent, been responsible for the tendency to use precooked ground beef patties and crumbles in school kitchens (Poppendieck, 2010). Fresh produce is a "raw agricultural product" that is also likely to have pathogens present and, when served raw, there is no "kill step" to eliminate contaminants. Large distributors provide assurances about the safety of the food they sell and buffer food service buyers from the responsibility of ensuring food safety practices during production and processing. However, when food service buyers purchase directly from farms, they become responsible for ensuring that the food was produced in a safe environment in addition to overseeing HACCP regulations in their kitchens.

The complicated regulations for school food procurement create another challenge. In some states, school food buyers are required to solicit at least three bids for any purchase that will be reimbursed with federal funds. Procurement procedures may be by either formal or informal bids. Federal regulations require a formal bid process whenever the spending is greater than US $\$ 100,000$, which requires publicly advertised bid requests, followed by sealed, written submissions from vendors. Local purchases usually remain small enough to require only an informal bid. In that case, buyers must still solicit and document at least three bids, but they do not have to be submitted sealed or in writing. Federal requirements stipulate that the buyer accept the lowest bid submitted, although he or she can accept a higher bid if the reason is documented. The geographic preference clause, for example, may be used as justification for accepting a higher bid.

Applying procurement regulations to local products becomes problematic when the food service buyer does not know which growers to con- 
tact for specific products. At a 2010 workshop on farm to school facilitated by the state's departments of education and agriculture, many food service directors, as well as the representatives from the state department of agriculture (SDA), had questions about how to apply procurement regulations to local purchasing. In particular, the staff members and SDA representatives were unsure how to proceed if there were not three vendors available who grow the requested item. The presenter, a representative from the Department of Education, cautioned the audience to carefully follow the procurement rules. One audience member questioned, "How much do you have to know about the grower? If they don't meet the specs [specifications], is that $\mathrm{OK}$, or does it look like you're purposely not following the rules?” The presenter responded that the food service buyer is responsible for finding out if the grower fits the specification. An exasperated food service employee sitting nearby exclaimed, "How?!" One suggestion was to use on-line price guides as bids. In an informal bid process, a buyer can look at public price listings of distributors or from the Chicago Board of Produce to compare prices with those of local growers. The mention of the Chicago Board of Produce caused a wave of protests from the SDA representatives, who pointed out that local growers likely cannot compete with commodity pricing.

The interactions that follow elucidate many of the barriers already identified to local procurement, including concerns about supply and delivery, food handling, and, in the Midwest, the temperamental spring weather. More importantly, this example also shows the different, sometimes oppositional, positions taken by food service buyers and farmers with regard to food handling and production. Their divergent views on what constitutes "safe" food become a significant procurement challenge. Ultimately, local food is acceptable to the institution only after elements of conventional distribution models are recreated.

\section{Farm to School in a Midwestern Community School District}

In January 2011, I started working with a farm to school program in a medium-sized Midwestern school district, initially as a volunteer. My connections with farmers resulting from my larger project led to my involvement with school food procurement. A parent volunteer, whom I will call Amy, ${ }^{1}$ directed the district's farm to school program. The group also included a food systems planner, a local grocery store manager, producer Neal Jackson ${ }^{1}$ and the district's food service director Carol HendelPatterson. ${ }^{1}$ Because the group initially had little idea of what local items Carol might want or be able to use, the first meetings were planned to better understand the lunch system in the district and to find out what local products might be useful to her.

The Midwestern Community School District ${ }^{1}$ (MCSD) consists of 24 schools: three high schools, three junior high schools, and 18 elementary schools. The district serves 12,000 students, who eat 6,500 school lunches and about 1,000 breakfasts each day. There are five production kitchens in the district: one at each of the three junior high schools and one in each of the two larger high schools. All of the elementary school lunches, as well as lunch for the alternative high school, are prepared in these five kitchens. Lunches are delivered in the mornings via a total of seven delivery routes, which are repeated in the afternoons to pick up leftovers, food carts, and trays.

Labor time and cost are important issues for the food service department. Carol, who has been the district food service director since 1986, pointed out to us that in the past she always purchased lettuces, carrots, and celery whole and her staff did the work to get them ready to eat. In an interview, I asked her about the reasons for the shift to pre-cut vegetables and found that they were complex. For one, she pointed out that when she started, the district had only 19 buildings (15 elementary schools, two high schools and two junior high schools) and served about 4,000 meals, as opposed to the 6,500 served currently. Carol noted, "essentially our facilities are still the same. We just added more serving sites." The increase in the number of lunches served also requires more food to be purchased, which puts storage space at

\footnotetext{
${ }^{1}$ Names of subjects and the school district have been changed to maintain their anonymity.
} 
a premium. Carol pointed out that whole lettuce, for example, takes up more cooler space than precut lettuce. She said, "that would actually be one of the first issues of getting lettuce in - we get produce in once per week, do we have room for all these uncut items?"

Finally, the regulations controlling what is offered in a school lunch have changed over time. When Carol started her job, there was no "offer versus serve," meaning that students were served a tray of food with one entrée, one fruit, one vegetable, and one grain serving. Now, she is required to offer two choices of fruit and two choices of vegetable. Carol noted, "hopefully, with the choices, that encourages them to take something they like"; however, it further adds to her preparation work. She told me that one of the major benefits of the pre-cut lettuce is that it gives her staff more time to prepare the other sides. "If you have lettuce that's ready to go, you can make the cole slaw, make the potato salad, do some of those other things - macaroni salads, fresh vegetable salads - some of those things that have a recipe and take a little more time." Add to all these issues the fact that her base labor cost is US $\$ 11.15$ per hour, and it becomes clearer why ready-to-eat items provide a significant benefit.

\section{Meeting with Carol}

These issues are just a few of the things the committee learned during their meetings with Carol; the group was also introduced to the nuances of school food procurement. Carol did not seem at all opposed to purchasing local foods; in fact she had purchased apples from a local orchard during the fall of 2010. Unfortunately, the grower could only supply three menus worth of apples before he risked diminishing supply for his regular customers. Carol pointed out her large supply needs; one day's requirement of apples, lettuce, or melons may be more than some growers produce in a single season. On the other hand, because of food safety concerns she was not open to purchasing local meat products. She purchases pre-cooked ground beef patties or crumbles. Using raw meat would require her staff to thaw it, then cook it, then cool and re-heat it before the delivery, as there would not be time to cook from scratch and deliver the meat the morning it would be served. This process would put the meal repeatedly in the temperature danger zone that might encourage bacteria growth.

The group left those first meetings with a lot of new information, but with no concrete plan to proceed. However, Amy hoped that a proposal for serving a local product in school lunches could be developed before the end of the year. She knew this was ambitious, particularly since the school year ended in early June and only a few items are abundantly ready in the early spring in the region. The group brainstormed several possibilities, such as radishes, peas, lettuce, spinach, or strawberries. Radishes seemed like a risky item to serve to children, and peas are often an expensive specialty item. Strawberries, even early bearers, likely would not be ready in time. That left lettuce and spinach - usually the first items to be found at markets in the early spring and something that many producers grow. The group agreed that a salad of mixed greens and spinach would be a suitable side for the school lunch menu. One of the group members, Neal Jackson, grew greenhouse sprouts; these were added to the list of possible additions to the salads. In addition, the chapter had received a US $\$ 900$ start-up grant from the SDA that could be applied to the cost of the lettuce. The committee planned to publicize the "Spring Greens Day" well and thought it would be a good way for the farm to school chapter to conclude its first school year. At this point, however, there was no information about how much mixed lettuce Carol would require for 6,500 salads or how much she would expect to pay for it. In addition, it was unclear if the kitchen staff would process the lettuce or if it would have to be delivered to the schools already washed and cut. The group did not know if they should seek out baby greens or mesclun mix, which because of its smaller size would presumably require less chopping, or look for head lettuce. With this "plan," which seemed to have as many questions as answers, the committee prepared for the next meeting with Carol.

Amy opened the next meeting by explaining the plan for the Spring Greens Day, and stated that she hoped to have a mix of lettuces and spinach and possibly sprouts. "No sprouts," Carol interrupted, shaking her head emphatically, "we don't 
do sprouts." As a potentially hazardous food (PHF), sprouts are often avoided in food service kitchens. Amy continued, discussing promotion and explaining that there would be press releases along with promotional materials in the cafeterias. Carol provided the group with the quantities she would need: 365 pounds $(166 \mathrm{~kg}$ ) of washed, bagged and ready-to-eat lettuce for one day. The lettuce she typically uses comes in 25-pound (11 $\mathrm{kg}$ ) cases, each case holding five five-pound (2.3 $\mathrm{kg}$ ) bags. The staff only had to open the bag and pour it into a tray; the students served themselves as they went through the line. The cost of the lettuce she usually buys is US $\$ 473$ for all 365 pounds, or US\$1.30 per pound. Carol said, "my guess is that we're not going to find local lettuce for a dollar a pound."

At this point, Amy brought up the US $\$ 900$ SDA grant, which we planned to use to offset any extra cost. Carol noted that she could not build a sustainable purchasing system by relying on grants. Further, she argued, even if producers gave us a break on cost, "we can't get a one-time 75 percent discount [on the lettuce] and let the public assume that now we'll always have local lettuce." While Carol was not opposed to using the SDA grant funding, she was understandably concerned about public perception and the development of a longterm local procurement system. Paying more for the lettuce, allowed by the grant, could become problematic if parents assume that local lettuce would suddenly become standard. On the other hand, it was equally unreasonable to assume that producers would be willing to meet her typical price point, even for a one-time event.

The next question for Carol was about the "ready-to-eat" designation: would the kitchen staff be able to do any preparation? Carol pointed out that she pays over US $\$ 11.00$ per hour for labor and they already offer four fruit and vegetable choices each day. They cut their own apples and oranges, so when they can get fresh produce, like lettuce, washed and ready to eat, that helps her labor cost significantly. Cutting the lettuce in the kitchen would certainly increase her labor costs by requiring additional staff or increased hours. If it were possible to get the lettuce inexpensively, she might be able to have her staff prepare it; however, she would prefer to have it ready to eat.

The group left that meeting with Carol's permission to contact growers for bids, roughly targeting a mid- to late May date for serving the lettuce. In addition, Carol indicated that "it would be fun" to visit farms that might supply the product. Finally, Carol wanted the producers to fill out a Grower Checklist for food safety, developed by the state land grant university, to keep in her files. These all seemed like straightforward, manageable requests, and so began the process of requesting bids and setting up farm visits.

\section{Contacting Producers}

I was asked to put together a bid letter to email to producers; this was sent out to eight growers and one local distributor in late March. Three producers did not respond to the email. The distributor requested more information about the bid deadline but did not have product available, and two growers indicated that their CSA businesses were too busy at that time of year. Three growers responded with interest, although one quoted a price of US $\$ 5.50$ per pound, well out of our price range. The other two growers indicated interest and flexibility on price, our target being between US $\$ 2.00$ and US $\$ 2.50$ per pound to fit within the constraints of the US $\$ 900$ grant. We were somewhat disappointed with the low number of responses to the bid request; however, conversations with other food service directors suggest that this is not unusual. For example, one food service director from a small district reported in an interview that she sent out 40 bid requests and received only two responses.

The two growers, David Evans ${ }^{2}$ of Century Farms and Rob Duncan, both felt they could meet the price constraints, though David noted that he "probably [wouldn't] make any money." David also pointed out that he would appreciate the publicity that his farm would receive from the project and that he was generally supportive of getting local foods into schools. Rob was more interested in having the business and was excited to have the opportunity to sell to the school district. Because

\footnotetext{
${ }^{2}$ Names of farmers and farms have been changed to maintain their anonymity.
} 
the farm to school group was still unsure whether the school kitchen staff would be able to cut head lettuce, or if we could use baby greens that would not require chopping, we indicated an interest in either product. Both growers operate CSA farms and sell to a nearby cooperative grocery store. Both were also used to selling their head lettuce by the head, rather than by the pound. Our request for a price per pound was problematic for both of them, as they would have to estimate the final weight of their head lettuce to ensure that we ended up with enough product. In addition, we would have to calculate the weight of the core of the lettuce, which would be cut away, and subtract it from their totals to ensure that we had enough finished, cut lettuce to deliver.

\section{Food Service Director Meets Farmer}

With this information in mind, we scheduled farm visits with both of them. Carol, Amy, and I traveled to Century Farms to get a look at our potential lettuce. David first took us through the packing shed, where in the summer months his crew would fill CSA boxes and prepare products for wholesale delivery. When we saw it, however, it was used for storing his tractor, potting soil, and several pallets. He warned us to watch our steps as we picked our way through the equipment and he described his process for washing mixed greens. He uses a product called Tsunami 100, which is a sanitizer approved for use in organic production. After harvest, the mixed greens are first submerged in cold water to quickly cool the leaves and maintain their freshness. They are then put into a solution of Tsunami 100 and water and finally rinsed again in clean water. David then spins the greens dry in a washing machine before packing them. He had plans to purchase a new salad harvester that would go on the back of the tractor. A band-saw blade would cut the leaves off just above soil level and they would be pushed into a basket. David noted that baby greens are incredibly labor intensive, particularly when harvested by hand. He was hopeful that the new harvester would improve his profitability on a product that is often, for him, a loss leader. He grows it because his customers are happy with the early spring salads, but he is still unable to charge enough to make a profit on it, even at the farmers market where he asks for US $\$ 3.50$ per pound.

David took us out to his fields, where tiny lettuce plants were just beginning to emerge. He cautioned us about the weather challenges that could make our mid-May date impossible. He also pointed out that he was growing head lettuce, which he could sell to us at our projected price. As we walked back to the car, we passed David's wife, Jessica, and three others cutting seed potatoes. Jessica indicated that she had some concerns about the Grower Checklist, which I had sent to her in advance of our visit. She also pointed out that the bid request specified ready-to-eat lettuce, and she reminded us that the farm is not licensed for processing. Thus none of its products should have been considered ready to eat; it should all be washed before consumption.

Jessica had not filled out the form and was not comfortable with several of the questions. She noted that many of the questions were vague and some important considerations, like liability insurance, were not addressed at all. For example, one question asked, "are storage and packing facilities located away from growing facilities?" Jessica wondered how far is far enough? Additionally, the question, "are wells protected from contamination?" was problematic for her. She said, "well, I hope so," but she wondered what, exactly, they should be protected from and what kind of protection is being suggested in the question - a fence, distance from livestock areas, a basic cap? Jessica wanted more information from Carol about her criteria for purchasing from a farm. Carol indicated that she would like to see temperature records on the walk-in cooler, as this is a standard procedure for food service personnel. These records are not maintained at Century Farms.

Carol noted that, based on David's explanation of the farm, she could see that they had put considerable thought into their post-harvest handling procedures. She liked that the produce came in on one side of the packing shed and was loaded out on the other side, minimizing the risk of clean product coming into contact with dirty product. Carol also liked David's description of the new salad harvesting procedure, as it would be done by machine and not be handled significantly. To this, 
Jessica responded that every item on the farm was harvested by hand, using a knife, without gloves. She leaned forward and raised a hand to emphasize her point. To Jessica, the handling of the produce was a benefit to her customers, as they knew each item was handled with care, rather than impersonally run through machine. Carol's food safety perspective led her to appreciate the mechanization of larger scale agriculture, where food was handled less and was, presumably, cleaner. Jessica, whose CSA shareholders and co-op customers desired "food with a face on it," the handling of produce signified the hands-on attention that set local food systems apart from industrialized agriculture.

Two days later, Carol, Amy, and I drove north to visit Rob Duncan. Rob was fixing equipment when we arrived and he told us that he has two main jobs: "growing stuff and breaking stuff." Rob had planted extra lettuce as soon as he heard about the Spring Greens event and also said that he had been thinking about processing possibilities. Like David Evans, he was not licensed to process, so his greens would not be ready to eat. However, if we had access to a commercial kitchen, perhaps at a hotel, we could get the product to meet the specifications. Rob recommended that the district purchase head lettuce, rather than baby greens or mesclun mix. Despite the fact that he sold a lot of small salad mix to restaurants, he was somewhat ambivalent about it. He noted that the mesclun is "burgie" 3 and that head lettuce was easier and more sustainable for him to grow, particularly from a labor standpoint. Additionally, he pointed out that chopped head lettuce might be more familiar to the elementary school kids, which might increase their consumption.

We walked through the fields first, where garlic, onions, and peas were already sprouting. Rob had six high tunnels, mobile plastic hoop structures that significantly increase production in the early spring and late fall. In one tunnel, he had lettuce, bok choy, spinach, and kale, some of which had been planted in the fall and overwintered in the tunnel.

\footnotetext{
${ }^{3}$ Rob used this term to indicate that the mesclun mix is somewhat "bourgeois" or elitist, and is primarily a high-priced status item.
}

In the packing area, Rob showed us his new walk-in cooler. He pointed out the stainless steel racks that let him keep product off the floor. Carol asked if he kept temperature records; he did not but said that he would be happy to keep them for her. He asked how often she would like them recorded and suggested that he could do it as often as hourly. Carol responded that her staff writes them three times per day, once in the morning, at midday, and before leaving in the afternoon. Carol also asked about hygiene standards for his employees. He noted that there was a flush toilet available and he had demonstrated the proper hand-washing procedure and nail-brush use. He also told us that he did not have any smokers on staff at the time, which is helpful because he did not have to explain to them why they are required to wash their hands after a smoke break.

Carol had mixed feelings about both farm visits. The lack of processing licensure on the farms made purchasing a ready-to-eat product impossible. Further, she was concerned that there were no current well-water tests available for either farm and that Century Farms did not document the manure schedule (although it was explained during the farm visit). In addition, the use of the washing machine to dry lettuce at Century Farms concerned her and she planned to ask her contact at the health department about that following the visit. Storing equipment in the packing shed at Century Farms was also a concern; she said, "I assume that it's clean and free of farm equipment during the summer, but I would like to see it being used." She noted that it would be "scary" to buy from Century Farms right now. "Well, not 'scary," she corrected herself, "but I would have concerns."

The next step was to figure out a way to get the lettuce ready to eat. Neal Jackson's greenhouse was licensed for processing, as his microgreens are sold as packaged and are officially designated as ready to eat. He offered the use of his space, even though the district would not be purchasing from him for the event. As we left Rob's farm, Carol commented that the "critical step" would be talking to Neal and learning more about his processing practices. However, while we worked to secure a date to visit Neal's facility, Carol made contact with the county department of public health. Her con- 
tact questioned whether either of the farmers we visited could be considered an "approved vendor" by the health department for the school district. Inn an email to the group and to the state farm to school representatives at SDA, Carol reiterated her concerns about the farms:

Lack of documentation for walk-in cooler temperatures, date of application of manure; lack of well water testing certificate; and [the] fact [that] neither farmer can meet the bid request which was ready-to-eat cut mixed greens since neither is a licensed processor... The other issue is whether or not the USDA requirement of trying to obtain 3 competitive bids is being met. At this time it appears there are only two growers with capacity to supply enough product, yet it is my sense pricing/ cost is still somewhat unclear. Until all these concerns can be addressed, I am hesitant to move forth with a Field Green menu day in June.

The email led Amy to assume that the project had reached a dead end. However, despite her concerns, Carol was still willing to visit Neal's greenhouse and discuss processing, so we planned to meet there the following week for a tour by Neal. He had put some thought into the purchasing process for the Spring Greens day. He noted that since his business would be the official processor for the lettuce, he would have to purchase it from David and Rob, and then sell it to the school.

When Carol arrived, he explained this to her, and she agreed. He would officially purchase the product, making his business liable should there be any problems with it. Neal showed Carol his processing area and went over his licensure. He was inspected by the State Department of Inspections and Appeals; the certification was posted above one of the refrigerators. Neal explained how the salads would be cut on the long stainless steel table and sanitized in a solution of Tsunami 100. Neal explained that the volunteers would be trained in the same way that he trains his employees. He uses what he calls a "no hands" policy, meaning that workers always wear gloves when they handle the product and long hair was always tied back.

Carol had very few questions about the pro- cess. She nodded a lot as Neal explained the process and when he was finished, she said, "that should all work fine." She did inquire about his liability insurance; his policy includes US $\$ 1$ million in liability, and he offered to fax her a copy of it. She indicated that would not be necessary and required no paperwork from him at all. For the rest of the group, this was remarkably anticlimactic, particularly considering the tone of some of the emails exchanged before the meeting. Neal's licensure ultimately erased the on-farm concerns, a process that Amy later referred to as "magic," and allowed us to move forward with the project. As Amy pointed out, the farms still lacked manure application records and well-water tests, two of Carol's major concerns. Neal's washing procedure was nearly identical to David's; both rinsed the greens in three separate water baths, using the exact same sanitizing product. The only significant procedural difference involved drying the lettuce: David used a washing machine where Neal had two industrial, food-grade salad spinners (which looked remarkably like washing machines). Neal also carried the documented blessing of the Department of Inspections and Appeals, which, from Carol's perspective, provided her with the institutional security of an officially inspected facility. Conducting the transaction with Neal's business, rather than directly with the farms, also provided a barrier between the school district and the site of production. Neal would ultimately be liable for any problems with the product.

\section{Never Again Lettuce}

This experience led Amy to quip at a statewide farm to school meeting that she would never again attempt to serve local salads to the entire school district. After all the work, the product fortunately was well received by the students. On the day the salads were served, Amy recruited volunteers to attend lunch in all the district's elementary schools to post signs and talk to students about the lettuce. The volunteers reported that many students had several servings of salad and responded positively. I visited two elementary schools and noticed that our lettuce was competing with fresh watermelon, canned peaches and hash-brown potatoes shaped like smiley faces. However, we later learned that 
just over half the lettuce we delivered was consumed and that the district disposed of the rest. Since it was served during the last week of school, there was no time to use the leftovers. Carol assured the group that had it been delivered a week earlier, she could have used the rest of the product in subsequent menus.

\section{Discussion}

What seemed like a relatively straightforward process - the purchase of one local item for school lunch - became extremely complicated. Even finding an appropriate item to serve, given the kitchens' labor and time constraints and the risky spring weather, was difficult. The initial desire to purchase lettuce from several producers was unrealistic, as only two were willing and able to both sell the required quantity and meet the budget. The growers were used to calculating their prices based on each head of lettuce. They had to estimate the final weight of their lettuce plants to provide the school with a total product weight. Carol's experience at the farms only heightened her concerns about local produce and on-farm food safety issues. While she was generally complimentary about the farms and impressed by the variety of food they were producing, she had many concerns about serving the food in her kitchens. In particular, she noted the lack of documentation of water quality, manure application, and walk-in cooler temperatures. In her job, documentation is critical to maintaining good records that, in case of a foodborne illness or other issue, can illuminate the source of a problem. Carol was especially surprised at the lack of temperature records for the walk-in coolers, as this is a basic procedure in her kitchens. Rosati and Saba assert that individuals tend to be more "worried about those food hazards that [are] well known to them" (2004, p. 499). In Carol's job setting, a cooler that is not holding food at the proper temperature may put products in the HACCP temperature "danger zone" and increase the risk of a food-borne illness. The producers' inattention to this basic hazard, regardless of whether her products would actually be in the coolers, signaled to her an overall lack of understanding of the food safety protocols she required. In addition, the mechanization of agriculture, often maligned by producers who value the personal attention their food receives, was perceived as a benefit to Carol, who would prefer that the food she serves be touched by human hands as infrequently as possible. Carol's complimentary statements about the lettuce harvesting at Century Farms, where the greens would be sliced directly into a basket rather than be cut by hand, were surprising to Jessica, who extolled the benefits of her hand-picked products. That her family and employees took the personal care to harvest products by hand sets her farm apart from large-scale, mechanized production where planting, weeding, and harvesting is managed entirely by machine or chemically. Interestingly, Carol did not question whether the blade that would cut the salad or the basket into which it would fall was of food-grade material. Public health professionals, including dieticians, often cite human hands as the numberone contaminant (Curtis, 2003; Lillquist, McCabe, $\&$ Church, 2005) and view machines, even those stored in farm equipment sheds, as inherently cleaner and safer.

Many food activists have suggested that small, localized food systems are safer than the industrial system (Hewitt, 2010; Pollan, 2006; Schlosser, 2001), in which centralized production and national distribution can result in lightning-fast spread of food-borne illnesses. Poppendieck notes, "product liability is at the manufacturer level” (2010, p. 96). Thus food that is prepared, or "manufactured," elsewhere, buffers the school from potential liability. However, with local food systems, where production is visible and raw agricultural products require further steps before becoming edible, the risks associated with food consumption are more apparent.

Carol's concerns about the on-farm food handling show how with more visibility, came an increase in her perception of the risk associated with local food. After having visited the farms, Carol contacted her regular suppliers to inquire about their requirements for growers. Interestingly, she learned that they do not have any of the information from growers that she was requiring from the local farmers (such as water testing information and chemical application schedules). However, their corporate assurances, coupled with significant 
liability insurance, effectively alleviated the potential risks associated with food production. Ultimately, when purchasing from a large distributor, Carol as food service director does not bear the entire responsibility for the safety of the food. She still must oversee the processes in her kitchens and ensure that her employees are following all food safety protocols (e.g., wearing gloves and hairnets and using good hygiene practices), but her distributor is responsible for the food-handling practices prior to delivery. Using local food requires that Carol also take responsibility for the processes on the farm, which has previously not been under her purview. The ultimate success of the project was based on our ability to use Neal's facility to process the lettuce and his willingness to take on the burden of distribution and liability. When he purchased and resold the lettuce to the school, in effect becoming the "manufacturer," he relieved Carol of the potential liability involved in directly purchasing and processing the lettuce in her own kitchens. Neal's business model closely resembles the vendors Carol typically works with, despite its small size. He has official paperwork from the Department of Inspections and Appeals, which validates his commitment to food safety. He documents cooler temperatures in the greenhouse and in the refrigerated truck and his liability insurance is adequate. His procedure is nearly identical to that of growers who are not inspected or certified, but the official inspection status validates his process to other institutions.

In summary, the key challenges in this project turned out not to be related to the more structural barriers of cost, supply, or delivery systems. The group had access to state funding and was able to fairly quickly identify growers who could provide the necessary quantity. The growers were able to be flexible with delivery and, despite differences in methods, were able to calculate the required quantity in advance. Finally, the project was able to offset the school's labor expenses by finding volunteers to wash and chop the lettuce. It was more difficult to overcome the different approaches to food handling and procedure. While all parties valued the inclusion of fresh, local food in school lunches, there were divergent opinions on the characteristics of the food. In this case, the local food farmer promoted the individual story of his or her hand-picked produce, whereas the food service director emphasized hygiene, uniformity, and documentation (see

Figure 1).

\section{Conclusions}

Recording experiences of interactions like these helps us better understand the often complicated process of making local foods acceptable for institutions. The consistent, high volumes required by

\section{Figure 1. System for Farm to School Success}

Though many of the structural barriers to farm to school programs are being addressed by public funding and volunteer engagement, addressing divergent values of participants has proven more difficult.

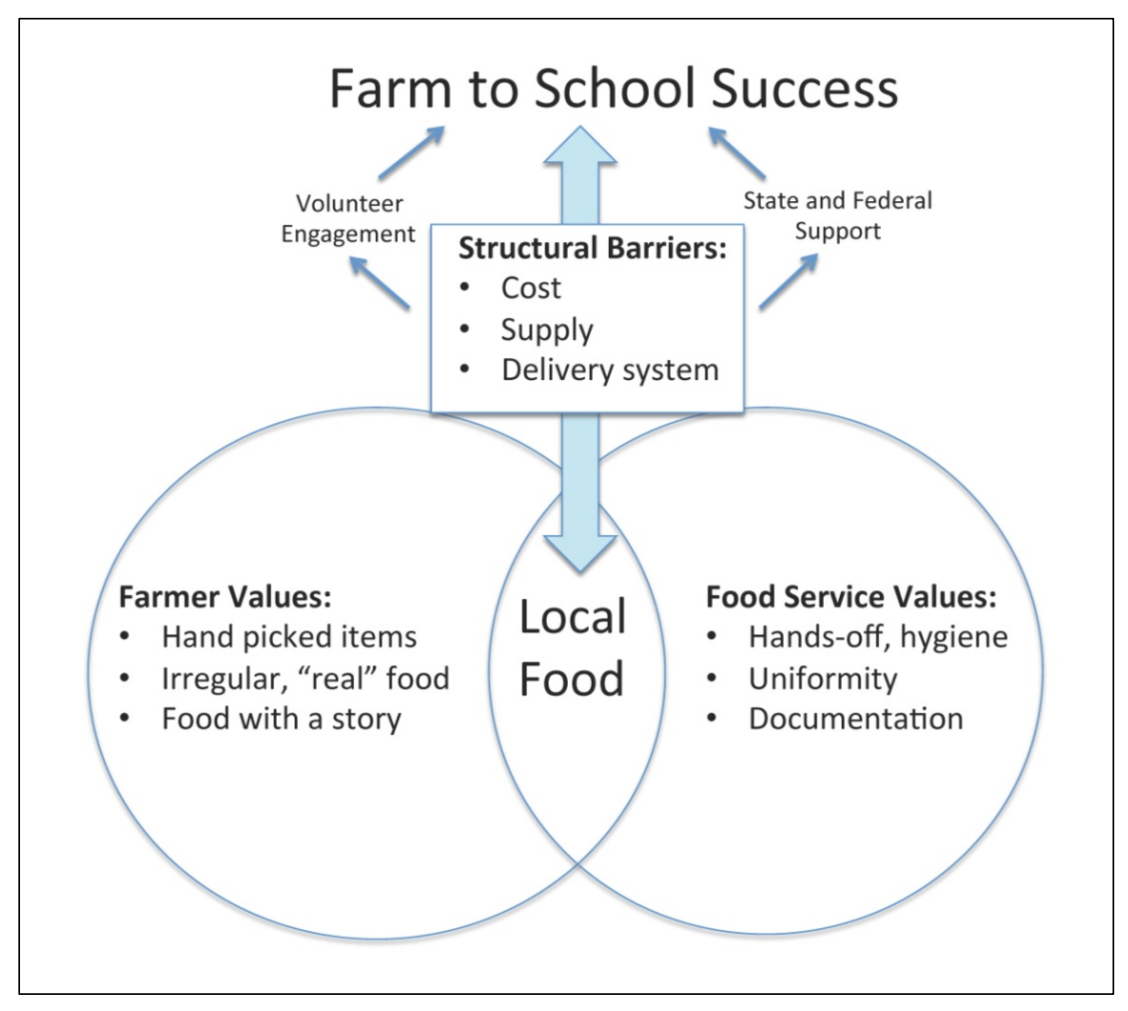


schools can potentially increase local food capacity. Many scholars have explored the structural barriers to local purchasing related to cost, supply, and distribution. These tangible barriers have also received the most attention and intervention. Grant programs from USDA along with state support and funding have provided financial resources and logistical support to school districts to build sustainable procurement systems. In addition, the popularity of farm to school has resulted in high volunteerism and community engagement around farm to school projects.

Nevertheless, the social interactions of various actors are also highly relevant and it is critical that farm to school practitioners recognize the extent to which different viewpoints about best practices can affect the purchasing process. Farmers and school food buyers may have vastly different approaches to food handling. Local food farmers have developed marketing strategies that emphasize individuality and personal handling of their products. School food service personnel, however, emphasize regularity and precise record-keeping, which ensures appropriate quantities and validates the safety of the food.

Farm to school practitioners can address some of these challenges by facilitating communication between farmers and food service directors whenever possible. Inviting farmers into school kitchens to observe the procedures and requirements of institutional kitchens will help them understand the high priority placed on food safety and documentation. Likewise, improving the agricultural literacy of food service personnel may reduce some of the fears about purchasing directly from farmers. Food service buyers who have no farming experience, like Carol in this case study, may be surprised by the fast-paced, and dirty, realities of growing and harvesting produce. Enhancing the farm to school component of the USDA Produce Safety University course with a farm field trip, or farmer guest speakers, could improve agricultural knowledge among food service staff. Ultimately, farm to school advocates will be best served by addressing knowledge gaps for both farmers and food service buyers.

More qualitative research in this area would be welcome. Additional data from interviews and focus groups with both farmers and food service directors could provide further insight into the challenges of introducing unprocessed, local products into institutional kitchens. In addition, ethnography, which attends to what participants both say and do, can illuminate subtle social barriers. Surveys and supply chain analyses may suggest that local purchasing is valued and feasible; however, close observation of participants' interactions reveals the ways that differences in knowledge, training, and point of view can create barriers for farm to school programs. Most beneficial may be a combination of methods in order to take a truly systemic approach, in which tangible barriers such as cost and supply are assessed along with qualitative attention to the knowledge and viewpoints of farmers, food service personnel, and farm to school volunteers (such as parents or teachers). Comparative studies across regions would improve our understanding of how farm to school programs are successful, or not, in different environmental and social contexts. Enhanced qualitative research in farm to school programs will shed further light on the dynamics of these interactions and could lead to a meaningful middle ground on which the farmer and the food service director can meet.

\section{References}

Bagdonis, J. M., Hinrichs, C. C., \& Schafft, K. A. (2009). The emergence and framing of farm-to-school initiatives: Civic engagement, health and local agriculture. Agriculture and Human V alues, 26(12),107-119. http://dx.doi.org/10.1007/s10460008-9173-6

Belasco, W. J. (2007). Appetite for change: How the counterculture took on the food industry ( $2^{\text {nd }}$ updated ed.). Ithaca, New York: Cornell University Press.

Cooper, A., \& Holmes, L. M. (2006). Lunch lessons: Changing the way we feed our children. New York: Harper Collins Publishing.

Curtis, V. (2003). Talking dirty: How to save a million lives. International Journal of Environmental Health Research, 13(Supplement 1), S73-S79. http://dx.doi.org/10.1080/0960312031000102822

DeLind, L. B. (1999). Close encounters with a CSA: The reflections of a bruised and somewhat wiser anthropologist. Agriculture and Human Values, 16(1), 3-9. http://dx.doi.org/10.1023/A:1007575521309 
Fink, D. (1998). Cutting into the meatpacking line: Workers and change in the rural Midwest. Chapel Hill: The University of North Carolina Press.

Friedmann, H. (2007). Scaling up: Bringing public institutions and food service corporations into the project for a local, sustainable food system in Ontario. Agriculture and Human Values, 24(3), 389398. http://dx.doi.org/10.1007/s10460-006-9040-2

Goldschmidt, W. (1978). As you sow: Three studies in the social consequences of agribusiness. Montclair, New Jersey: Allanheld, Osmun.

Grey, M. A. (2000). "Those bastards can go to hell!" Small-farmer resistance to vertical integration and concentration in the pork industry. Human Organization, 59(2), $169-176$. http://sfaa.metapress.com/content/113218/

Hamm, M. W. (2008). Linking sustainable agriculture and public health: Opportunities for realizing multiple goals. Journal of Hunger and Environmental Nutrition, 3(2-3), 169-185. http://dx.doi.org/10.1080/19320240802243241

Hewitt, B. (2010). The town that food saved: How one community found vitality in local food. New York: Rodale.

Horwitz, R. P. (1998). Hog ties: Pigs, manure, and mortality in American culture. New York: St. Martin's.

Ikerd, J. E. (2011). Local food: Revolution and reality. Journal of Agricultural and Food Information, 12(1), 49-57.

http://dx.doi.org/10.1080/10496505.2011.540557

Izumi, B. T., Alaimo, K., \& Hamm M. W. (2010). Farmto-school programs: Perspectives of school food service professionals. Journal of Nutrition Education and Behavior, 42(2), 83-91. http://dx.doi.org/10.1016/j.jneb.2008.09.003

Janssen, B. (2010). Local food, local engagement: Community-supported agriculture in eastern Iowa. Culture and Agriculture, 32(1), 4-16. http://dx.doi. org/10.1111/j.1556-486X.2010.01031.x

Joshi, A., Misako Azuma, A., \& Feenstra, G. (2008). Do farm-to-school programs make a difference? Findings and future research needs. Journal of Hunger and Environmental Nutrition, 3(2-3), 229-246. http://dx.doi.org/10.1080/19320240802244025

Kloppenburg, J., Jr. (1991). Social theory and the $\mathrm{de} /$ reconstruction of agricultural science: Local knowledge for an alternative agriculture. Rural
Sociology, 56(4), 519-548. http://dx.doi.org/ 10.1111/j.1549-0831.1991.tb00445.x

Kloppenburg, J. R. Jr., Lezberg S., De Master, K., Stevenson, G. W., \& Hendrickson, J. (2000). Tasting food, tasting sustainability: Defining the attributes of an alternative food system with competent, ordinary people. Human Organization, 59(2), 177-186. http://sfaa.metapress.com/content/113218/

Lillquist, D. R., McCabe M. L., \& Church, K. H. (2005). A comparison of traditional handwashing training with active handwashing training in the food handler industry. Journal of Environmental Health, 67(6), 13-16.

Lyson, T. A. (2004). Civic agriculture: Reconnecting farm, food, and community. Medford, Massachusetts: Tufts University Press.

Murray, D. L., \& Raynolds, L. T. (2000). Alternative trade in bananas: Obstacles and opportunities for progressive social change in the global economy. Agriculture and Human Values, 17(1), 65-74. http://dx.doi.org/10.1023/A:1007628709393

National Farm to School Network. (n.d.). The benefits of farm to school. Retrieved from http://www.farmto school.org/Resources/BenefitsFactSheet.pdf

Pollan, M. (2006). The omnivore's dilemma: A natural history of four meals. New York: Penguin Books.

Poppendieck, J. (2010). Free for all: Fixing school food in America. Berkeley, California: University of California Press.

Rich, R. (2006). "This little piggy went to market; this little piggy stayed home": Contracts and live-hog markets in Illinois, 1993-2000. Culture and Agriculture, 28(1), 45-63. http://dx.doi.org/10.1525/cag.2006.28.1.45

Roche, E., \& Kolodinsky, J. M. (2011). Overcoming barriers to providing local produce in school lunches in Vermont. Journal of Agriculture, Food Systems, and Community Development, 1(3), 89-97. http://dx.doi.org/10.5304/jafscd.2011.013.012

Rosati, S., \& Saba, A. (2004). The perception of risks associated with food-related hazards and the perceived reliability of sources of information. International Journal of Food Science and Technology, 39(5), 491-500. http://dx.doi.org/10.1111/j.13652621.2004.00808.x 
Schlosser, E. (2001). Fast food nation: The dark side of the all-American meal. New York: Harper Perennial.

Story, M., Nanney, M. S., \& Schwartz, M. B. (2009). Schools and obesity prevention: Creating school environments and policies to promote healthy eating and physical activity. Milbank Quarterly, 87(1), 71-100. http://dx.doi.org/10.1111/j.14680009.2009.00548.x

Stull, D. D. (2000). Tobacco barns and chicken houses: Agricultural transformation in western Kentucky.

Human Organization, 59(2), 151-161. http://sfaa.metapress.com/content/113218/

Swenson, D. (2009). Investigating the potential economic impacts of local foods for southeast Iowa. Ames, Iowa: Leopold Center for Sustainable Agriculture, Iowa State University. Retrieved from http://www.leopold.iastate.edu/pubs-andpapers /2010-01-local-foods-southeast-iowa

U.S. Department of Agriculture [USDA]. (2014). National count of farmers market directory listing graph: 1994-2014. Retrieved Dec. 3, 2014, from
http://www.ams.usda.gov/AMSv1.0/FARMERS MARKETS

Vogt, R. A., \& Kaiser, L. L. (2008). Still a time to act: A review of institutional marketing of regionallygrown food. Agriculture and Human V alues, 25(2), 241-255. http://dx.doi.org/10.1007/s10460-0079106-9

Winter, M. (2003). Embeddedness, the new food economy and defensive localism. Journal of Rural Studies, 19(1), 23-32. http://dx.doi.org/10.1016/S0743-0167(02)00053-0

Ziegenhorn, R. (1996). An alternative model: Swine producer networks in Iowa. In K. M. Thu \& E. P. Durrenberger (Eds.), Pigs, profits, and rural communities (pp. 170-182). Albany, New York: State University of New York Press.

Ziegenhorn, R. (2000). The commodification of hybrid corn: What farmers know. In A. Haugerud, M. P. Stone, \& P. D. Little (Eds.), Commodities and globalization (pp. 135-150). Lanham, Maryland: Rowman and Littlefield. 